\title{
Attaining human dignity for people with birth defects: A historical perspective
}

\author{
A L Christianson, MB ChB, FRCP (Edin) \\ Arnold Christianson heads the Division of Human Genetics, National Health Laboratory Service and University of the Witwatersrand, \\ Johannesburg, South Africa
}

Corresponding author: A L Christianson (arnold.christianson@nhls.ac.za)

\begin{abstract}
People with birth defects have been stigmatised, marginalised and discriminated against for millennia, diminishing their human dignity and abrogating their human rights. Beginning with the United Nations Universal Declaration of Human Rights, promulgated in 1947, the circumstances in which human dignity in healthcare for people with birth defects could be achieved arose, and this was accomplished over the next 65 years through the insight, hard work and dedication of a select group of people and organisations. In 2010 the World Health Organization prioritised services for the care and prevention of birth defects, particularly in middle- and low-income countries. Translating what has been achieved into human rights in healthcare for people with birth defects is the next objective.
\end{abstract}

S Afr Med J 2013;103(12 Suppl 1):1014-1019. DOI:10.7196/SAMJ.7277

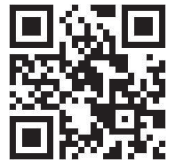

Dr Jonathan Mann (1947 - 1998), health visionary and activist, highlighted the significance of human dignity in healthcare, particularly with respect to violations of human dignity. Recognising the social marginalisation, stigmatisation and lack of respect for the dignity and rights of people with HIV/AIDS, he defined the relationship between human dignity and human rights in healthcare. In a paper published after his death he brought to our attention that although 'all human beings are born free and equal in dignity and rights', dignity comes before the rights. To Mann, ${ }^{[1]}$ human dignity is 'the bedrock of all that follows ... the wellspring and basis for universal human rights'.

Human dignity 'is a linguistic currency that will buy you a basketful of extraordinary meanings. ${ }^{[2]}$ To encapsulate its meaning in a manner relevant to people with birth defects. I will use Nora Jacobson' ${ }^{[3]}$ definition contained in her comprehensive review of dignity and health:

Human dignity is the inherent and inalienable value that belongs to every human being simply by virtue of being human. Human dignity is held by the species, by collectives (groups or peoples), and by individuals. It cannot be measured or weighed or destroyed; nor is it contingent, conditional, contextual, or comparative. ${ }^{[3]}$

This is intuitively understandable, encompassing religious and secular approaches to human dignity. Jacobson ${ }^{[3]}$ concludes that both

Since first meeting and working with Trefor Jenkins in 1990, I have appreciated his devotion to and teaching of the ethical practice of medicine, and his insistence on according people, particularly patients, human dignity and thus their rights. In applying his principles he has quietly, and with dignity, shown courage beyond the measure of most men.

In this article I wish to honour that commitment by considering how the impairment of human dignity for people with birth defects arose over time, and then recognise the organisations and individuals who have worked assiduously, particularly over the last 65 years, to achieve dignity for people with birth defects. allow at the collective level ... justification for sociopolitical ideals of equity and justice'.

Mann, ${ }^{[1]}$ recognising the complexity in adequately defining human dignity, turns rather to classifying violations of human dignity in healthcare. He places these into four categories: being ignored or insufficiently acknowledged; being seen, but only as a member of a group; having one's personal space transgressed involuntarily; and humiliation.

People with birth defects, that is with any structural or functional abnormality present from birth, certainly in Mann's terms, suffer marginalisation, discrimination and stigmatisation. ${ }^{[1,4]}$ From a health sciences and public health perspective, their presence, until recently, was ignored or insufficiently acknowledged. ${ }^{[1]}$ It can be argued that when seen, they are seen as a group whose needs are all too often attended to as a lesser priority than those of the whole. Collectively, they were for millennia 'distinguished and separated' from the family of humankind, that is, humiliated ${ }^{[1]}$ In essence, I believe that their human dignity has been, until recently, impaired. ${ }^{[1]}$

In what follows I will describe a brief history of birth defects until the mid 1940s, and thereafter detail the international efforts to develop a cogent healthcare approach and policies for people with birth defects. In conclusion, I will describe the current situation, particularly in middle- and low-income nations, after the World Health Organization (WHO)'s May 2010 World Health Assembly (WHA) decision to make birth defects a global health priority ${ }^{[5]}$

\section{Looking back at birth defects}

People with birth defects have been part of the human condition since humankind first walked the earth. Early humankind's reaction to birth defects, that is those born with severe structural abnormalities, included 'admiration, awe or terror'. ${ }^{[6]}$ Responses included killing them, sometimes making images of their likeness in drawings, sculptures and carvings, and at times idolising or mythologising the images.

Our first knowledge of people with a birth defect is the statue of conjoined twins, the Goddess of Anatolia. Dating from 6500 BC, it was found in 1962 in southern Turkey. ${ }^{[6]}$ Since then images of people with congenital malformations have been found worldwide, 
in different countries and cultures. Noah, following a description by his great-grandfather, the prophet Enoch, is possibly the first person described with a birth defect - albinism..$^{[7]}$

The Tablets of Nineveh, containing the first written record of congenital malformations (loosely in this paper structural abnormalities), were discovered in the ruins of Babylon and date to the 7th century BC. One tablet describes 62 different malformations, each with a prognostic statement, mostly adverse, from the Babylonian diviners. Thus, 'if a woman gives birth to an infant that wants [for] both ears, there will be mourning in the country and the country will be lessened [diminished] ${ }^{[6]}$

Divination from infants and children with malformations, which continued overtly into the Middle Ages and covertly to the 20th century in Europe, did not, however, give a cause for these problems. For aetiology, many theories have been proposed over time and in different cultures and countries. Among these is maternal impression, the concept that the development of the fetus is influenced by parental psychological factors around conception or in pregnancy. Thus things seen by the parents, particularly the pregnant woman, can by photographic transmutation affect the fetus. For example, a prevalent myth was that looking at monkeys, because of their head shape, was a cause of microcephaly or anencephaly. Not only visual images are considered to cause abnormality. Maternal shock, stress, worry and alarm could produce malformation, ${ }^{[6]}$ and such ideas persist today.

More extreme is the ancient idea that malformed children were the product of the crossbreeding of humans and animals. Possibly having its origin in Egypt and India, there is evidence of this belief being upheld in Europe and America in the late 17th century. Related to it was the theory, particularly prevalent in 15th and 16th century Europe, that malformed children were caused by hybridisation of the mother and some demonic being. ${ }^{[6]}$ In the absence of scientific knowledge, superstition will take its place, and even when science steps in to fill the void, displacing the superstition from the collective psyche is not automatic, as evidenced by the existence of some of these superstitions today. Against this background it is easily understood how past concepts about congenitally malformed children induced violations of human dignity for people with birth defects, and more recently have retarded the acquisition of this dignity.

Overturning such myths began in the 16th century with the growing knowledge of embryology. Among the first contributors, William Harvey (1578 - 1657) introduced the teratology concept of congenital malformations being the result of arrested embryological development. ${ }^{[6]}$ Further work on this concept by Étienne Geoffroy Saint Hilaire (1772 - 1844) showed that arrested development could be caused by environmental agents, thus giving the first causative factor for birth defects. ${ }^{[6,8]}$ However, it was his son and successor, Isidore Geoffroy Saint Hilaire (1805 -1861), who arguably, but unknowingly, struck the first blow for human dignity for people with birth defects. He recognised that congenital malformations were more common than naturalists at that time considered. ${ }^{\left[{ }^{[0]}\right.}$ Jonathan Mann, ${ }^{[1]}$ describing the process of clarification of new problems in healthcare, when referring to the epidemiology of the problem notes that the issue of concern is often found to be more extensive than was assumed'. To my knowledge, Saint Hilaire's observation on the frequency of congenital malformations is the first intimation of the extent of the problem of birth defects, a problem that was only to be fully understood more than 180 years later. However, he had begun the process of allowing people with birth defects to be acknowledged.

Perhaps more significantly, Isidore Saint Hilaire, in conjunction with Charles Darwin (1809 - 1882), is responsible for ensuring that people with birth defects are not distinguished and separated from the group or social norm, that is, collectively humiliated. ${ }^{[1]}$ The group or social norm in this instance is the species, humankind. The early history of people with birth defects depicts them as a distinct group, not essentially human, whose existence was caused by hybridisation with animals or demonic figures or who were other-worldly beings, mythologised or idolised in images. ${ }^{[6]}$

Darwin, in On the Origin of Species ${ }^{[10]}$ and based on Saint Hilaire's work, considered congenital malformations in plants and animals as 'some considerable deviation in one part, either injurious or not useful to the species ... but they graduate into varieties ... and monstrosities (congenital malformations) cannot be separated by any clear line from mere variations. He affirmed that naturalists include in one species its congenital malformations and varieties. ${ }^{[10]}$ In The Descent of Man, ${ }^{[11]}$ Darwin confirmed that ' $[\mathrm{M}]$ onstrosities, which graduate into slight variations, are likewise so similar in man and the lower animals ... the same terms can be used for both, as has been shown by Saint Hilaire. The combined efforts of Saint Hilaire and Charles Darwin thus brought people with birth defects firmly into the human family.

However, Darwin's work, totally independent of himself, led to horrendous consequences for people with birth defects in the late 19th and 20th centuries. On a misreading of Darwin's work and its inappropriate application to society (persons, groups and races), his cousin Francis Galton proposed the concept of eugenics. Galton first defined eugenics in 1883, but refined his definition and concepts over time. In a paper read in 1904 before a Sociological Society meeting in the London University's School of Economies, he defined it as 'the science that deals with all influences that improve the inborn qualities of a race; also those that develop them to the utmost advantage. ${ }^{[12]}$ Its aim was 'to bring as many influences as can be reasonably employed to cause the useful classes in the community to contribute more than their proportion to the next generation. ${ }^{\left[{ }^{[12]}\right.}$ To achieve this, Galton was far more interested in, and motivated mainly for, what is now termed positive eugenics - his 'augmentation of the favoured stock. $\mathrm{He}$ considered that 'The possibility of improving the race of a nation ... is far more important than repressing the productivity of the worst. ${ }^{?[12]}$

While eugenics never officially gained favour in the UK and was opposed by such doyens of human genetics as J B S Haldane, Lancelot Hogben and Julian Huxley, its emigration to other countries, particularly the USA, Canada, Scandinavia and Germany, resulted in its transmogrification into appalling legislated and practised negative eugenics. ${ }^{[13]}$

Negative eugenics prescribes improving the quality of the human race by eliminating or excluding biologically inferior people from the population. ${ }^{[13]}$ The definition of 'biologically inferior' was broadly, socially and politically based and biased, bearing little resemblance to biology, let alone reality. The inhumane consequences of this in the USA are starkly described in Stephan J Gould's essay 'Carrie Buck's daughter, ${ }^{[14]}$ which vilifies the 1927 Supreme Court decision in Buck vs Bell. Chief Justice Oliver Wendell Holmes, in his infamous majority decision, had said:

It is better for all the world, that instead of waiting to execute degenerate offspring for crime, or let them starve for their imbecility, society can prevent those who are manifestly unfit from continuing their kind. The principle that sustains compulsory vaccination is broad enough to cover Fallopian tubes. Three generations of imbeciles is enough. ${ }^{[14]}$

Carrie Buck, along with over 50000 others in state institutions, was sterilised. She was later considered to be of normal intelligence, albeit unsophisticated! $!^{[14]}$ 
There is little doubt that people with birth defects, 'three generations of imbeciles', were central to Holmes' decision. But worse was to follow. In Nazi Germany between 1939 and 1945, following the Euthanasia Action (Aktion T4) ordered personally by Adolf Hitler on his private stationery, children with congenital disorders were put to death. They were murdered by State decree. ${ }^{[15]}$

\section{New era, new approach}

In 1948, in a brief moment of universal enlightenment and rationality, the world's nations ratified the United Nation's Universal Declaration of Human Rights (UDHR). What happened prior to this has resonance with the story above and to follow.

In June 1941, fourteen Allied nations signed the Inter-Allied Declaration, the founding step of the United Nations (UN). Two months later President Franklin Delano Roosevelt (FDR) and Winston Churchill signed the Atlantic Charter, a set of principles for international collaboration for maintaining world peace and security. On 1 January 1942, representatives from 26 Allied nations signed the Declaration by United Nations. After World War II the UN Charter was ratified in October 1945 and the first General Assembly was held in London on 10 January 1946. An early order of business was to complement the UN Charter with a road map to guarantee the rights of all peoples. The UN committee to draft the UDHR was chaired by Eleanor Roosevelt, widow of FDR. The first sentence of the UDHR recognises that 'the inherent dignity and the equal and inalienable rights of all members of the human family is the foundation of freedom, justice and peace in the world. ${ }^{\left.{ }^{[16,1]}\right]}$ Thus began an era wherein, despite the inhumanity of Man towards his fellow Man that preceded it, people globally now have a framework to turn to, to achieve justice. This includes doctors and others responsible for the healthcare of people with birth defects.

FDR developed polio at 39 years of age in 1921. In 1938, at his behest, the National Foundation for Infantile Paralysis, later the March of Dimes, was founded, in his words 'to lead, direct, and unify the fight on every phase of this sickness. For FDR the new Foundation, in the words of historian Saul Benison, '... stood as an affirmation of the value of conserving human life and dignity. ${ }^{3[1]}$ In 1958, the March of Dimes made a remarkable decision. Founded to defeat polio, by the mid-1950s its task largely complete, the March of Dimes required a new mission. Turning away from an infectious disease to the field of non-communicable disorders, it chose to confront the challenge of birth defects. In this it was the first major organisation, national or international, to enter the field. ${ }^{[18]}$

The March of Dimes decision preceded the 1959 planning of the first international study on the epidemiology of birth defects, by the WHO, and the birth of the field of clinical genetics as announced by Dr Victor McKusick. ${ }^{[19,20]}$ The latter is considered to have resulted from the burgeoning knowledge in the basic science fields of inborn errors of metabolism, cytogenetics, immunogenetics, population genetics and molecular genetics. The time was ripe for a clinical arm to translate that knowledge into healthcare for people with birth defects.

There is another, equally important reason why the time was right for the introduction of medical genetic services. In 1963 Dr Candau, Director-General of the WHO, in his opening address to the WHO Expert Committee on Human Genetics and Public Health, noted that 'with increasing control of infant mortality and infectious diseases, inherited abnormalities are assuming a proportionately greater importance in medical practice. What Dr Candau refers to is health transition, otherwise known as epidemiological transition. ${ }^{[2,22]}$

Health transition occurs positively in most countries and is the change in population health (decreasing infant and child mortality rates with increasing longevity) and patterns of diseases in a country or region consequent on socioeconomic, educational, infrastructural and healthcare development and improvement. These initially bring about a reduction of infant and childhood deaths from infectious diseases and malnutrition, ensuring that more people can live longer into middle age, and then into old age as the process continues. With these changes, the pattern of diseases transforms from predominantly infectious diseases to non-communicable disorders, chronic disorders of later life, which often have a genetic component to their cause, and birth defects, which now attain public health significance. ${ }^{[21]}$

From 1959 to today we have witnessed remarkable developments in human and medical genetics, an amazing upsurge in knowledge and technology. ${ }^{[23]}$ More remarkable, I believe, is how rapidly this new knowledge and technology has been translated into healthcare, particularly for people with birth defects. And this has been done with great attention to ensuring that the translation, and its practice in medicine, is ethically undertaken. Missteps have occurred, something to be expected in such a complex field, but these were for the most part recognised early and remedial action was taken.

Thus in a short 50 years, medical genetic services underpinned by ethical considerations, particularly the autonomy of those affected and their parents, have flourished. From the healthcare perspective these services acknowledge people with birth defects, who as a group now have their health needs integrated into healthcare and prioritised. By the turn of the 21st century these services were widely available to the populations in high-income (developed) nations. They highlighted industrialised nations' successful health transition and the need therein for healthcare for people with or at risk of birth defects. ${ }^{[2,24,25]}$ However, the healthcare benefits derived from the human and medical genetic revolution accrued little advantage to the millions of people born with birth defects (and their parents) in developing nations. ${ }^{[2,24,25]}$ This was because 'the common view [is] that a genetics service is an inappropriate luxury [in developing countries] where malnutrition and infection are still important problems. ${ }^{[26]}$ In the early 1980 s a different view emerged. The main authors of this view were Dr Anver Kuliev, head of the Hereditary Diseases Programme at the WHO, and Professor Bernadette Modell, of University College London, who worked with him as a WHO expert advisor. The thrust to cross the last divide in achieving human dignity in healthcare for all people with birth defects began and was to take 30 years.

Kuliev and Modell recognised that health transition was proceeding in many developing nations, and for these countries developing medical genetic services was a looming priority. They understood that 'inherited and other chronic diseases are more common [in developing countries], and their burden falls much more heavily on the family', and that, because of circumstances and health services being very different in these countries, a new approach to offering medical genetic services was required. Their suggestion was 'approaches that can be applied at the community level ... a group of community genetic services, relevant to many aspects of primary health care. The question was 'when and how to introduce community genetics services into developing health systems. ${ }^{\text {[26] }}$ When developing countries should introduce medical genetic services was to take up some time and effort, but was ultimately extraneous to the process. The real issue was to how to introduce and develop these services. The answer was eventually offered in the March of Dimes Global Report on Birth Defects. ${ }^{[21]}$ All countries require medical genetic services, but these have to be appropriate to their needs and current circumstances. For most developing nations the clinical services will mainly be community genetic services, or aspects thereof, integrated into and offered through primary healthcare. ${ }^{[21]}$ 
However, this realisation was some time in the future, and much had to be achieved before it was appreciated.

As medical genetic services were established in high-income countries, so they were started in developing nations. Individuals from developing countries trained in medical genetics in highincome countries and on returning home established academic medical genetic departments, research-orientated but offering clinical services, much as in the high-income countries. ${ }^{[25]}$ These academic clinical services tended to provide only limited access for the majority of the population.

There were two notable exceptions to these approaches in developing countries at that time. One medical geneticist from the developing world, who recognised this problem and wrote and spoke in an effort to change the approach, was the Argentinean Dr Victor Penchaszadeh. A medical geneticist and human rights activist, he was to play a central role in the future development of approaches to healthcare for people with birth defects and their parents in developing countries. The other was Cuba. ${ }^{[27]}$ In the 1980s and early 1990s Cuba established the most comprehensive medical genetic service in the developing world, offering universal genetic healthcare to its population.

The insight and efforts of these early campaigners bore fruit in the 1990s. The work of different individuals and organisations began to converge to form a network dedicated to providing appropriate medical genetic services, mainly through primary healthcare, in developing nations.

Foremost among the organisations were the March of Dimes and the WHO. In 1992 Dr Michael Katz, following an outstanding career in paediatrics at Columbia University's College of Physicians and Surgeons, was appointed Senior Vice President for Research and Global Programs at the March of Dimes. In 2006 he wrote a paper outlining the remarkable successes achieved by the March of Dimes in its fight against polio, and later through its support of research in human and medical genetics. ${ }^{[28]}$ This included sponsoring James Watson's fellowship to the UK that resulted in his collaborating with Francis Crick to publish their paper on the structure of DNA. In concluding, Dr Katz mentioned another March of Dimes accomplishment: the March of Dimes Global Report on Birth Defects. ${ }^{[21]}$ I believe that the work of the March of Dimes Global Programs will in time be considered alongside that which has been achieved in the organisation's genetic research portfolio.

In November 1997, Michael Katz and Ysbrand Poortman visited South Africa. Representing the World Alliance of Organizations for the Management and Prevention of Congenital Disorders (WAO), established in 1994 as an international consortium to increase awareness of birth defects through education and financial support, they held a meeting with three South African medical geneticists. At the conclusion of this meeting the WAO issued the Cape Town Declaration. Recognising the significant number of children born with birth defects in developing nations, and the need to translate current knowledge and technology to services appropriate for their healthcare, the Declaration recommended that an international conference should be held to discuss implementing these goals. What the Cape Town Declaration did not address was the need for the provision of medical genetic services in developing countries to be confronted by the WHO. Michael Katz offered to raise the issue with the WHO in Geneva.

In 1996, independent of the above activities, the Eastern Mediterranean Regional Office of the WHO, under the directorship of Dr Ala Alwan, held a meeting of regional medical genetic experts to discuss approaches for community control of genetic and congenital disorders. The international advisor to this meeting was Bernadette Modell, and the report produced was the first of its kind to focus on community approaches to healthcare for people with or at risk of having a child with a birth defect. ${ }^{[29]}$ The report still has relevance today.

Independently of each other, Michael Katz and Ala Alwan, now based in Geneva, cleared the way for two landmark meetings to be held in 1999. Michael Katz raised the funding to enable the Human Genetics Programme of the WHO, in conjunction with the WAO, to convene a meeting of expert advisors in The Hague in January of that year. Chaired by Victor Penchaszadeh, this gathering highlighted two significant issues. The first was the lack of reliable empirical epidemiological data on birth defects from developing countries. The second was the primacy of providing services for the care of people with birth defects in developing countries. Care was defined as diagnosis, treatment and counselling, with psychosocial support for people with birth defects as well as their parents. Historically, in most industrialised nations, the focus had been on the provision of preventive services. ${ }^{[24]}$

The second meeting, arranged by Ala Alwan in Cairo in December 1999, looked specifically at primary healthcare approaches for people with or at risk of birth defects. This group recommended a threephase approach for medical genetic services in developing countries: (i) to produce a structured country plan (Health Needs Assessment); (ii) to undertake intervention studies based on this plan; and (iii) to implement services based on the success of the intervention studies. Again, recognising the paucity of available epidemiological data, the meeting made practical recommendations for how countries could undertake base-line epidemiological studies. ${ }^{[30]}$

The turn of the century brought with it the very real prospect of medical genetic services finally being made available, in a meaningful way, in developing countries. Plans were laid to do pilot programmes in selected countries. From these it was hoped that sufficient knowledge, data, including epidemiological data, and experience would be acquired to change existing misperceptions regarding the need for these services in developing countries. In turn it was considered that the successful undertaking of these national pilot projects and their translation to national medical genetic services would drive the globalisation of these services, bringing with it human dignity, and in turn rights, for people with birth defects.

Jointly sponsored by the South African National Department of Health, the March of Dimes and the Centers for Disease Control (CDC), Atlanta, USA, the 1st International Conference on Birth Defects and Disabilities in the Developing World was successfully held in Johannesburg, South Africa, in September 2001. Emanating out of the WAO Cape Town Declaration, this was the first of five bi-annual conferences to be held in different regions of the world. The sixth is to be held in the Philippines in November 2013.

But storm clouds were gathering. In 2001 the WHO discovered a new holy grail - genomics and world health. ${ }^{[31]}$ The WHO attempted to get medical geneticists and others involved with medical genetic services in developing countries to fully espouse its Genomic and World Health Programme. At a WHO meeting of expert advisors on 'Collaboration in Medical Genetics', held in Toronto in April 2002, neither collaboration nor consensus was achieved.

In 2001, Ala Alwan was posted to Jordan as the WHO representative. Most of those who had previously been involved with the WHO in the field of medical genetic services in developing countries now worked to advance their cause outside of its sphere of influence. There was much to do. The 1999 meetings had highlighted the lack of adequate global epidemiological data on birth defects. Without such data it would be difficult to persuade governments in developing countries, let alone the WHO, of the need for medical genetic services in developing countries. 
In 1998, the WHO initiated a programme to document childhood mortality from congenital anomalies. ${ }^{[32]}$ Congenital anomalies cover significantly fewer disorders than the term birth defects. They include structural abnormalities of genetic origin - chromosomal abnormalities, multifactorial malformations and some singlegene defects. Excluded are all functional abnormalities, including the haemoglobin disorders, glucose-6-phosphate dehydrogenase deficiency and occulocutaneous albinism (common in Africa), some single-gene defects, and post-conception disorders due to abnormalities of the fetal environment (e.g. fetal alcohol syndrome and congenital rubella syndrome).

After the 1999 Cairo meeting, Bernadette Modell began work on modelling the global birth prevalence of birth defects. The basic principle for deriving this modelled database was the same as that concurrently being applied by the WHO to congenital anomalies. ${ }^{[2,34]}$ However, the Modell Birth Defects Database encompassed all birth defects and sourced important data from two largely unknown but important studies ${ }^{[3,34]}$ She completed her work towards the end of 2002.

Meeting in Lyon in April 2001, representatives of patient-parent support groups from around the world, under the chairmanship of Ysbrand Poortman (a global doyen of patient-parent support for people with birth defects), considered options for creating an international organisation. Convening again in Lyon in 1993, the International Genetic Alliance of Parent and Patient Organisations (IGA) was established. The IGA collaborates with the organisations previously mentioned and works with its own agenda to promote medical genetic services, research, technologies and access to information, to alleviate the burden of birth defects on individuals, families and communities.

Two significant events occurred in 2004. The 2nd International Conference on Birth Defects and Disabilities in the Developing World took place in the Great Hall in Beijing, China. In his address, before an audience of almost 1000 people, the Chinese National Deputy Minister of Health highlighted the global need for healthcare services for people with birth defects. In addition, he opened a declaration, to be forwarded to the WHO, for consideration and signature by the delegates, and proposed 15 September as World Birth Defects Day.

Then the March of Dimes commissioned its Global Report on Birth Defects (the Report) in 2004. The Modell Birth Defects Database was reconfigured for easier access and analysis, and used as the basis for the report. Published in early 2006, the Report including the Modell Birth Defects Database - received worldwide press attention and prompted an immediate response from the WHO. The Report's figures for the total birth prevalence of genetic and partially genetic (multifactorial) birth defects far exceeded previous considerations. ${ }^{[2]}$ More disquieting for the WHO was that the figures for childhood deaths from birth defects exceeded those previously published by a factor of six. ${ }^{[2,32,35]}$ Given that the WHO child health policy is predicated on such data, and that the Report had adverse implications for the achievement of Millennium Development Goal 4 (MDG 4), the WHO's response was to be expected.

Four months later, at a joint WHO-March of Dimes expert advisors meeting in Geneva, the experts endorsed the March of Dimes Global Report on Birth Defects' modelled estimates for the global birth prevalence of, and deaths from, birth defects. ${ }^{[4]}$ Isidore Saint Hilaire's observation on the frequency of birth defects was supported, and a major advance towards achieving human dignity in healthcare for people with birth defects had been made.

Professor Irma Nippert has been integrally involved in the development and delivery of medical genetic services in Europe since the 1980s. She joined the global movement at the meeting held in The Hague in 1999. A medical sociologist and an expert in medical genetic healthcare issues related to women and children, she brought a critical perspective to all proceedings. In 2003 she became the WAO chairperson and with her global network of colleagues and organisations tackled the practical issues that had been neglected after the world health and genomics issue.

Following EuroGentest, a European Union initiative to standardise and harmonise genetic testing in Europe, Irma Nippert initiated the CAPABILITY programme. ${ }^{[36]}$ This was a European Commission-funded programme, started in 2005, to investigate how to translate current knowledge and technology into practice in developing countries and to see if standards could be harmonised with those being established for Europe by EuroGentest. ${ }^{[3]}$ Three developing countries, Argentina, Egypt and South Africa, were involved. Valuable lessons were learnt on how to initiate and develop medical genetic services. In Argentina, the programme initiated in one province has now been extended to others. Following the Cairo 1999 concept, CAPABILITY developed an approach for Health Needs Assessment that developing countries could use. Then the PHG Foundation, based in Cambridge, UK, a CAPABILITY consortium partner, put together a toolkit to assist in the performance of a Health Needs Assessment. ${ }^{[38]}$

Following CAPABILITY, Irma Nippert initiated Genetic Testing in Emerging Economies (GenTEE) in 2010, a project designed to assess the current medical genetic service development and capacity of eight emerging economies. The GenTEE report is being finalised prior to publication. One concern noted during the project was that most of the countries have not used the WHO proposed community genetic model for the universalisation of their services. They have tended to follow the industrialised country academic centre model, thereby limiting access to these services by large portions of their populations, particularly the poor.

In 2008, Ala Alwan returned to the WHO in Geneva as Assistant Director-General for Noncommunicable Diseases and Mental Health. Under his guidance the executive board of the WHO, at the request of China, placed a document on birth defects before the WHA in May 2010. In consideration of that document, the WHA passed resolution WHA63.17 $7^{[5]}$ on 21 May. This resolution recognised, among other issues, the contribution of birth defects to infant and childhood mortality and that services for the care and prevention of birth defects, including community genetic services, were necessary to reduce this mortality, to help countries to attain MDG 4. It also recognised that the infrastructure was not in place in developing countries to acquire the necessary empirical epidemiological data to assess and recognise the public health significance of birth defects, and this in turn led to limited resources being allocated to services for the care and prevention of birth defects.

Mindful of the above, the WHA urged member states to raise awareness among all relevant stakeholders about the importance of birth defects as a cause of child morbidity and mortality; set priorities, commit resources, and develop plans and activities for integrating effective interventions for the care and prevention of birth defects into existing maternal, reproductive and child health services and social welfare; include ethical, legal and social issues associated with birth defects into their considerations; foster the development of parent-patient organisations; establish appropriate community genetic services; develop and strengthen registration and surveillance systems for birth defects within the framework of national health information systems; and take all necessary measures to ensure the full enjoyment by people with disabilities of all human rights and fundamental freedoms on an equal basis with other people. The vision of Bernadette Modell and Anver Kuliev and the endeavours of all involved had come to fruition. 


\section{The future: attaining human rights}

The passing of the WHO's resolution WHA63.17 $7^{[5]}$ can be considered as the moment when people living with birth defects were finally offered human dignity in healthcare. In healthcare they are no longer ignored or insufficiently acknowledged; if seen as a group they are part of the community of humankind, no longer humiliated; and their needs are prioritised along with all others in our community. That realised, the next goal to achieve for people with birth defects is their human rights in healthcare. This can be accomplished by ensuring the best possible healthcare in the circumstances for all people with birth defects. Obviously best possible care is contingent upon each country's situation and available resources. But once healthcare for people with birth defects is initiated, that is a beginning. As national circumstances improve, so can the healthcare for people with birth defects transform.

Some developing countries are on the road to achieving human rights in healthcare for people with birth defects. Their efforts, and the enthusiasm of the champions who undertake this task, mostly under trying circumstances, are laudable. They stand as examples for other developing countries to follow. Foremost among these countries is Iran. It is progressing towards comprehensive, universal medical genetic services for its over 44 million people, who live in a large country with diverse geographical and climatic conditions. It is achieving this by undertaking a Health Needs Assessment, based on both available empirical and modelled epidemiological data, and developing the clinical genetic services with a strong base in the community. ${ }^{[39]}$

Another concern raised by the GenTEE project is that in most of the emerging nations involved, a significant portion of healthcare for people with birth defects is rendered in the private healthcare sector. If this trend continues, and possibly increases, it could financially exclude millions of poor people with birth defects access to healthcare, raising issues concerning their human rights in healthcare.

In conclusion, Resolution WHA63.17 $7^{[5]}$ of the World Health Assembly of the World Health Organization gives people with birth defects human dignity in healthcare. It is to be hoped that their human rights will follow. The efforts of many organisations and people working towards this objective over the past 65 years ensure that Roosevelt's ideal in establishing the National Foundation for Infantile Paralysis in 1938 has also been achieved for people with birth defects: 'the affirmation of the value of conserving human life and dignity'.

1. Mann J. Dignity and Health: The UDHR's Revolutionary First Article. Health Hum Rights 1998;3(2):3038. [http://dx.doi.org/10.2307/4065297]

Horton R. Rediscovering human dignity. Lancet 2004;364(9439):1081-1085. [http://dx.doi.org/10.1016/ S0140-6736(04)17065-7]

3. Jacobson N. Dignity and health: A review. Soc Sci Med 2007;64(2):292-302. [http://dx.doi.org/10.1016/j. socscimed.2006.08.039]
4. World Health Organization \& March of Dimes. Management of Birth Defects and Haemoglobin Disorders. Geneva: WHO, 2006. http://www.who.int/genomics/publications/WHO-MODreport-final. pdf (accessed 24 March 2013).

. World Health Organization. Sixty Third World Health Assembly - Birth Defects. Geneva: WHO, 2010. http://apps.who.int/gb/ebwha/pdf_files/WHA63/A63_R17-en.pdf (accessed 24 March 2013).

http://apps.who.int/gb/ebwha/pdf_files/WHA63/A63_R17-en.pdf (accessed 24 March

6. Warkany J. Congenital Malformations. Chicago: Year Book Medical Publishers, 1971 .
7. Sorsby A. Noah - an albino. In: Sorsby A, ed. Tenements of Clay. New York: Charles Scribner \& Sons, 1974. . Sorsby A. Noah - an albino. In: Sorsby A, ed. Tenements of Clay. New York: Charles Scribner \& Sos
Saint-Hilaire EG. Philosophie Anatomique des Monstruosité Humaines. Paris: Rignaux, 1822.

9. Francis KA. Charles Darwin and the Origin of Species. Westport: Greenwood, 2007.

10. Darwin C. On the Origin of Species. Facsimilie of the First Edition. Cambridge: Harvard University Press, 1859 [1964].

1. Darwin C. The Descent of Man. New Edition. London: John Murray, 1871 [1901].

2. Galton F. Eugenics: Its definition, scope and aims. Am J Sociol 1904;10(1):1-25. [http://dx.doi. org/10.1086/211280]

3. Kelves DJ. In the Name of Eugenics. Berkeley: University of California Press, 1985.

14. Gould SJ. Carrie Buck's daughter. In: McGarr P, Rose S, eds. The Richness of Life. London: Vintage Books, 2007.

15. Weingart P, Kroll J, Bayertz K. Rasse, Blut und Gene: Geschichte der Eugenik und Rassenhygiene in Deutschland. 3rd ed. Frankfurt am Main: Suhrkamp Verlag, 2001.

16. United Nations. The Universal Declaration of Human Rights. 2013. http://www.un.org/en/documents/ udhr/index.shtml (accessed 24 March 2013).

udhr/index.shtml (accessed 24 March 2013).
17. Trindade AAC. Universal Declaration of Human Rights. New York: United Nations Audiovisual Library Trindade AAC. Universal Declaration of Human Rights. New York: United Nations Audiovisual Library
of International Law, 1948. http://untreaty.un.org/cod/avl/ha/udhr/udhr.html (accessed 24 March 2013) of International Law, 1948. http://untreaty.un.org/cod/avl/ha/udhr/udhr.html (accessed 24 .
Rose D. March of Dimes - Images of America. Charleston: Arcadia Publishing, 2003.

19. McKusick VA. The growth and development of human genetics as a clinical discipline. Am J Hum Genet 1975;27(3):261-273.

20. Stevenson AC, Johnston HA, Stewart MIP, et al. Congenital Malformations: A Report of a Study of a Series of Consecutive Births in 24 Countries. Geneva: WHO, 1966.

1. Christianson AL, Howson C, Modell B. March of Dimes Global Report on Birth Defects. 2006. http:// www.marchofdimes.com/globalprograms (accessed 24 March 2013).

22. World Health Organization. Human Genetics \& Public Health: Second Report of the WHO Expert Committee on Human Genetics. Technical Report Series No. 282. Geneva: WHO, 1964.

23. McKusick VA. History of medical genetics. In: Rimoin DL, Connor JM, Pyeritz RE, Korf BR, eds. Emery and Rimoin's Principles and Practice of Medical Genetics. 5th ed. London: Churchill Livingstone, 2007.

World Healt Organization. Serves for

World Health Organization. Services for the Prevention and Mandent of Genetic Disorders and Birth Defects in Developing Countries. Geneva: WHO, 1999.

25. Christianson A, Modell B. Medical genetics in developing countries. Annu Rev Genomics Hum Genet 2004;5:219-265. [http://dx.doi.org/10.1146/annurev.genom.5.061903.175935]

26. World Health Organization. Community Approaches to the Control of Hereditary Diseases: Report of a WHO Expert Advisory Group. Geneva: WHO, 1985. http://www.who.int/genomics/publications/ WHOHGNWG85.10.pdf (accessed 24 March 2013)

27. Heredero L. Comprehensive national genetic program in a developing country - Cuba. Birth Defects Orig Artic Ser 1992;28(3):52-57.

28. Katz M. A genetics pioneer focused on child health challenges. Nat Neurosci 2006;9(10):1211. [http:// dx.doi.org/10.1038/nn1006-1211

29. Alwan A, Modell B. Eastern Mediterranean Regional Office Technical Publication Series 24. Community Control of Genetic and Congenital Disorders. Alexandria, Egypt: Regional Office of the Eastern Mediterranean, 1997.

30. World Health Organization. Primary Health Care Approaches for the Prevention and Control of Congenital and Genetic Disorders. Geneva: WHO, 2000.

31. World Health Organization. Genomics and World Health: Report of the Advisory Committee on Health World Health Organization. Gen.
Research. Geneva: WHO, 2002.

32. Murray CIL, Lopez AD. Health Dimensions of Sex and Reproduction: The Global Burden of Sexually Murray CJL, Lopez AD. Health Dimensions of Sex and Reproduction: The Global Burden of Sexually
Transmitted Diseases, HIV, Maternal Conditions, Perinatal Disorders and Congenital Anomalies. Transmitted Diseases, HIV, Maternal Conditiox

Boston: Harvard School of Public Health, 1998.

33. Baird PA, Anderson TW, Newcombe HB, et al. Genetic disorders in children and young adults: A population study. Am J Hum Genet 1988;42(5):677-693.

34. Czeizel A, Sankaranarayanan K. The load of genetic and partially genetic disorders in man. I. Congenital anomalies: Estimates of detriment in terms of years of life lost and years of impaired life. Mutat Res 1984;128(1):73-103. [http://dx.doi.org/10.1016/0027-5107(84)90049-6]

35. Bryce J, Boschi-Pinto C, Shibuya K, et al. WHO estimates of the causes of death in children. Lancet 2005;365(9465):1147-1152. [http://dx.doi.org/10.1016/S0140-6736(05)71877-8]

36. CAPABILITY. Capacity building for the transfer of genetic knowledge into practice and prevention. http://www.capabilitynet.eu/ (accessed 4 September 2013).

37. EuorGenTest. Harmonising genetic testing across Europe. http://www.eurogentest.org (accessed 4 September 2013).

38. PHG Foundation. Health needs assessment toolkit. http://toolkit.phgfoundation.org/ (accessed 4 September 2013).

39. Samavat A. Genetic epidemiology in Iran - a basis for service development. PhD thesis, University College London, 2009.

Accepted 27 August 2013 